\title{
Pengaruh Partisipasi Penganggaran dan Penekanan Anggaran pada Senjangan Anggaran dengan Komitmen Organisasi sebagai Variabel Pemoderasi
}

\author{
Ni Nyoman Putri Widiari ${ }^{1}$ \\ Fakultas Ekonomi dan Bisnis \\ Universitas Udayana, Indonesia
}

\author{
Luh Gede Krisna Dewi² \\ Fakultas Ekonomi dan Bisnis \\ Universitas Udayana, Indonesia
}

\begin{abstract}
Surel : putriwidiari1997@gmail.com
\section{ABSTRAK}

Anggaran sektor publik merupakan instrumen pemerintah daerah untuk mewujudkan pertumbuhan dan stabilitas perekonomian daerah. Penelitian ini bertujuan untuk menguji secara empiris kemampuan komitmen organisasi dalam memoderasi pengaruh partisipasi penganggaran dan penekanan anggaran pada senjangan anggaran. Penelitian ini dilakukan di 30 Organisasi Perangkat Daerah (OPD) Kabupaten Klungkung. Jumlah sampel yang diambil sebanyak 90 orang. Jumlah responden yang dianalisis sebanyak 68 orang dengan menggunakan metode purposive sampling. Pengumpulan data dilakukan menggunakan kuesioner. Teknik analisis data yang digunakan adalah uji nilai selisih mutlak. Berdasarkan hasil analisis menunjukkan bahwa komitmen organisasi memperlemah pengaruh positif partisipasi penganggaran pada senjangan anggaran dan komitmen organisasi memperlemah pengaruh negatif penekanan anggaran pada senjangan anggaran.

Kata Kunci: $\quad$ Partisipasi Penganggaran; Penekanan Anggaran; Komitmen Organisasi; Senjangan Anggaran.

\section{Effect of Budgetary Participation and Budget Emphasis on Budgetary Slack with Organizational Commitment as Moderating Variables}

\begin{abstract}
The public sector budget is an instrument of the regional government to realize growth and stability in the regional economy. This study aims to empirically examine the ability of organizational commitment to moderate the effect of budgetary participation and budgetary emphasis on budgetary slack. This research was conducted in 30 OPD Klungkung Regency. The number of samples taken was 90 people. The number of respondents analyzed was 68 people using the purposive sampling method. Data collection was carried out using a questionnaire. The data analysis technique used is the absolute difference test. Based on the results of the analysis show that organizational commitment weakens the positive influence of budgetary participation on budgetary slack and organizational commitment weakens the negative influence of budgetary emphasis on budgetary slack.
\end{abstract}

Keywords: Budgeting Participation; Budget Emphasis; Organizational Commitment; Budgetary Slack.

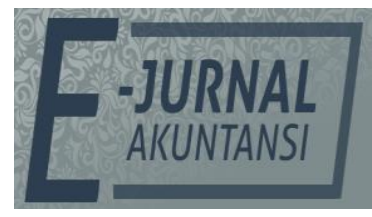

e-ISSN 2302-8556

Vol. 30 No. 10

Denpasar, Oktober 2020

Hal. 2551-2561

DOI:

10.24843/EJA.2020.v30.i10.p09

PENGUTIPAN:

Widiari, N. N. P \& Dewi, L.

G. K. (2020). Pengaruh

Partisipasi Penganggaran dan Penekanan Anggaran pada Senjangan Anggaran dengan Komitmen

Organisasi sebagai Variabel Pemoderasi. E-Jurnal Akuntansi, 30(10), 2551- 2565

RIWAYAT ARTIKEL: Artikel Masuk: 24 Juni 2020 Artikel Diterima: 14 September 2020

Artikel dapat diakses : https://ojs.unud.ac.id/index.php/Akuntansi/index 


\section{PENDAHULUAN}

Anggaran merupakan pernyataan mengenai estimasi kinerja yang hendak dicapai selama periode waktu tertentu yang dinyatakan dalam ukuran finansial (Mardiasmo, 2018: 75). Anggaran terdiri dari jumlah sumber daya yang harus dialokasikan dan digunakan yang dinyatakan dalam istilah ekonomi atau moneter (Carreras \& Gil, 2014). Dalam suatu organisasi, anggaran memberikan efektivitas dalam mencapai efisiensi organisasi dengan membatasi pengeluaran dan mencegah pengeluaran berlebihan (Tagwireyi, 2012). Dalam organisasi pemerintah atau sektor publik, anggaran memiliki beberapa fungsi utama yaitu sebagai alat perencanaan, pengendalian, kebijakan fiskal, motivasi, politik, komunikasi dan koordinasi, penilaian kinerja serta sebagai alat untuk menciptakan ruang publik (Mardiasmo, 2018: 75).

Sejak diberlakukannya otonomi daerah yang diatur dalam Undangundang Nomor 23 Tahun 2014 tentang pemerintah daerah menyebabkan terjadinya reformasi penganggaran. (Dewi, 2013) mengungkapkan bahwa reformasi penganggaran ini merupakan perubahan dari sistem anggaran tradisional (traditional budget system) ke sistem anggaran berbasis kinerja (performance budget system). Menurut Suartana (2010: 138), sistem anggaran berbasis kinerja merupakan proses pembangunan yang efisien dan partisipatif dengan harapan dapat meningkatkan kinerja agen. Namun, penilaian kinerja berdasarkan tercapai atau tidaknya target anggaran akan mendorong agen melakukan senjangan anggaran (budgetary slack) demi jenjang karir yang lebih baik di masa mendatang.

Senjangan anggaran merupakan perbedaan antara perkiraan biaya yang dilaporkan dengan jumlah riil yang sesungguhnya dibutuhkan untuk memenuhi kebutuhan organisasi (Faria \& Silva, 2013). Senjangan anggaran terjadi akibat seseorang sengaja meninggikan perkiraan biaya dan menurunkan perkiraan pendapatan (Harvey, 2015). Indikasi senjangan anggaran terlihat saat anggaran direalisasikan. Senjangan anggaran terjadi apabila realisasi pendapatan cenderung melampaui target yang dianggarkan dan realisasi belanja cenderung dibawah target yang dianggarkan (Mahasabha \& Ratnadi, 2019).

Tabel 1. Ringkasan Realisasi Anggaran Pendapatan dan Belanja Daerah (APBD) Kabupaten Klungkung Tahun Anggaran 2014-2018 (dalam jutaan rupiah)

\begin{tabular}{ccccccc}
\hline Tahun & $\begin{array}{c}\text { Anggaran } \\
\text { Pendapatan } \\
\text { Daerah }\end{array}$ & $\begin{array}{c}\text { Realisasi } \\
\text { Pendapatan } \\
\text { Daerah }\end{array}$ & $\begin{array}{c}\text { Persentase } \\
(\%)\end{array}$ & $\begin{array}{c}\text { Anggaran } \\
\text { Belanja } \\
\text { Daerah }\end{array}$ & $\begin{array}{r}\text { Realisasi } \\
\text { Belanja } \\
\text { Daerah }\end{array}$ & $\begin{array}{c}\text { Persentase } \\
(\%)\end{array}$ \\
\hline$(1)$ & \multicolumn{1}{c}{$(2)$} & \multicolumn{1}{c}{$(3)$} & \multicolumn{1}{c}{$(4)$} & \multicolumn{1}{c}{$(5)$} & \multicolumn{1}{c}{$(6)$} & $(7)$ \\
\hline 2014 & 815.707 & 827.029 & 101,39 & 911.519 & 781.329 & 85,91 \\
2015 & 878.773 & 913.367 & 103,94 & 1.016 .975 & 897.183 & 88,22 \\
2016 & 1.056 .820 & 1.028 .633 & 97.33 & 1.126 .130 & 1.063 .649 & 94,45 \\
2017 & 1.032 .084 & 1.098 .962 & 106,47 & 1.146 .304 & 1.020 .000 & 88,98 \\
2018 & 1.139 .596 & 1.100 .138 & 96,53 & 1.094 .695 & 1.032 .226 & 94,29 \\
\hline
\end{tabular}

Sumber: www.klungkungkab.go.id, 2019

Pada Tabel 1, menunjukkan indikasi senjangan anggaran dalam APBD Kabupaten Klungkung pada tahun 2014-2018 yang dilihat dari realisasi pendapatan daerah yang biasanya cenderung lebih tinggi dari pendapatan yang 
dianggarkan, selain itu realisasi belanja daerah selalu lebih rendah daripada yang dianggarkan. Hal ini kemungkinan sengaja dilakukan agar target anggaran lebih mudah dicapai sehingga kinerja pemerintah terlihat seolah-olah baik (Mahasabha \& Ratnadi, 2019). Pada tahun 2016 dan 2018, realisasi pendapatan daerah tidak mencapai 100 persen disebabkan oleh pendapatan yang belum mencapai target.

Dipilihnya Kabupaten Klungkung dalam penelitian ini, dikarenakan adanya indikasi senjangan anggaran pada laporan realisasi APBD Kabupaten Klungkung tahun 2014-2018. Selain itu, juga dikarenakan adanya kasus korupsi penyalahgunaan APBD untuk pengadaan instalasi biogas di Kecamatan Nusa Penida (Surya-Antara Bali News dalam http:/ / Antarabalinews.com, 2019). Hal ini sejalan dengan hasil penelitian Windarti (2015) yang menyatakan bahwa terdapat hubungan positif antara senjangan anggaran dengan tingkat korupsi di Indonesia. Senjangan anggaran akan memberikan ruang lebih kepada pihak eksekutif untuk menentukan batasan minimal pencapaian organisasi. Berdasarkan hal tersebut, maka semakin tingginya senjangan anggaran yang dibuat oleh pihak eksekutif maka semakin besar kecenderungan untuk melakukan tindakan korupsi di Indonesia.

Salah satu faktor yang sangat mempengaruhi terjadinya senjangan anggaran adalah partisipasi penganggaran. Partisipasi pengganggaran adalah proses yang menggambarkan individu-individu terlibat dalam penyusunan anggaran dan mempunyai pengaruh terhadap target anggaran dan perlunya penghargaan atas pencapaian target anggaran tersebut (Falikhatun, 2007). Partisipasi penganggaran memungkinkan bawahan untuk bertanggungjawab atas kinerja anggaran dan berpartisipasi dalam pengembangan anggaran. Lavarda \& Almeida (2013). Pada proses penganggaran terdapat hubungan keagenan antara agen dan prinsipal yakni adanya benturan kepentingan ketika mereka termotivasi untuk mencapai kemakmurannya masing-masing, agen cenderung akan memberikan masukan estimasi anggaran yang tidak sesuai dengan kapasitas sebenarnya yang dimiliki organisasi. Hal inilah yang menyebabkan terjadinya senjangan anggaran.

Beberapa penelitian mengenai hubungan partisipasi penganggaran dengan senjangan anggaran telah dilakukan, tetapi masih ditemukan adanya inkonsistensi penelitian. Penelitian Widanaputra \& Mimba (2014) pada organisasi sektor publik menyatakan bahwa partisipasi penganggaran berpengaruh positif pada senjangan anggaran. Hal ini didukung oleh hasil penelitian yang dilakukan oleh Ajibolade \& Akinniyi (2013), Savitri \& Sawitri (2014), serta Mahasabha \& Ratnadi (2019) menunjukkan bahwa partisipasi penganggaran memiliki pengaruh positif dan dapat meningkatkan terjadinya senjangan anggaran. Namun, hal tersebut tidak sejalan dengan hasil penelitian dari Djasuli \& Fadilah (2011), Karsam (2013), Savitri \& Sawitri (2014), serta Chong \& Strauss, (2017) yang menyimpulkan bahwa semakin tinggi partisipasi penganggaran justru dapat menurunkan terjadinya senjangan anggaran

Selain partisipasi penganggaran, senjangan anggaran juga dipengaruhi oleh penekanan anggaran. Penekanan anggaran merupakan pemberian penghargaan atau apresiasi kinerja bawahan atas pencapaian target anggaran (Dunk, 1993). Ketika anggaran dijadikan indikator penilaian kinerja seseorang 
dalam organisasi, hal tersebut akan mendorong bawahan untuk meningkatkan kinerjanya dengan cara meningkatkan performance sehingga dapat melampaui target anggaran atau dengan melonggarkan anggaran pada saat penyusunan anggaran (Sujana, 2010).

Pratami \& Erawati (2016), Erina \& Suartana (2016) mengungkapkan bahwa penekanan anggaran memiliki pengaruh positif pada senjangan anggaran. Namun hasil berbeda ditemukan oleh Lestari \& Putri (2015) serta Chong \& Strauss (2017) yang menunjukkan bahwa penekanan anggaran berpengaruh negatif pada senjangan anggaran. Selain itu, hasil penelitian Sujana (2010) menunjukkan bahwa penekanan anggaran tidak berpengaruh pada senjangan anggaran yang artinya penekanan anggaran tidak meningkatkan dan juga tidak menurunkan terjadinya senjangan anggaran. Perbedaan hasil penelitian yang ada dapat diselesaikan melalui pendekatan kontijensi (Govindarajan, 1986). Pemakaian pendekatan kontijensi memungkinkan adanya variabel-variabel lain yang dapat bertindak sebagai faktor moderating yang mempengaruhi hubungan partisipasi penganggaran dan penekanan anggaran pada senjangan anggaran.

Dalam penelitian ini, peneliti menggunakan komitmen organisasi sebagai variabel pemoderasi. Komitmen organisasi merupakan keyakinan dan dukungan pada nilai dan sasaran yang ingin dicapai oleh organisasi (Syahputra, 2014). Alasan dipilihnya komitmen organisasi sebagai variabel pemoderasi karena konsep komitmen organisasi sejalan dengan teori stewardship yang menggambarkan situasi dimana manajemen tidak termotivasi oleh tujuan-tujuan individu tetapi lebih ditujukan pada kepentingan organisasi (Sudaryo et al., 2017:60). Mahadewi (2014) dan Irfan et al., (2016) menyatakan bahwa komitmen organisasi mampu memperlemah pengaruh partisipasi penganggaran pada senjangan anggaran. Selain itu, penelitian Wulandari (2017) dan Perdani (2019) yang menyatakan bahwa komitmen organisasi mampu memperlemah pengaruh penekanan anggaran pada senjangan anggaran.

Penelitian ini termotivasi oleh penelitian Mahasabha \& Ratnadi (2019) yang meneliti pengaruh partisipasi penganggaran dan penekanan anggaran pada senjangan anggaran dengan internal locus of control sebagai variabel pemoderasi di OPD Kabupaten Badung. Hal yang membedakan penelitian ini dengan penelitian sebelumnya yaitu peneliti menggunakan komitmen organisasi sebagai variabel pemoderasi, dan menggunakan lokasi penelitian yang berbeda yaitu di OPD Kabupaten Klungkung. Alasan penulis tertarik untuk meneliti kembali topik senjangan anggaran dikarenakan masih adanya inkosistensi hasil penelitian pada riset-riset terdahulu, dan dikarenakan adanya indikasi senjangan anggaran pada laporan realisasi APBD Kabupaten Klungkung tahun 2014-2018.

Berdasarkan uraian latar belakang tersebut, tujuan dilakukannya penelitian ini yaitu: "untuk menguji secara empiris kemampuan komitmen organisasi dalam memoderasi pengaruh partisipasi penganggaran dan penekanan anggaran pada senjangan anggaran."

Konsep senjangan anggaran dapat dijelaskan melalui teori keagenan. Menurut (Jensen \& Meckling, 1976), Teori keagenan merupakan "teori yang menjelaskan mengenai kontrak yang terjadi antara prinsipal dengan agen serta menunjuk orang lain sebagai agen dalam melaksanakan jasa untuk pengambilan 
suatu keputusan". Dalam penelitian ini, Agen adalah OPD yang bertanggung jawab untuk merencanakan, melaksanakan, serta melaporkan anggarannya kepada Kepala Daerah yang bertindak sebagai prinsipal. Selain itu, konsep senjangan anggaran sejalan dengan teori atribusi. Teori yang dicetuskan oleh Fritz Heider (1958), menyatakan bahwa "perilaku penyusun anggaran dipengaruhi oleh atribusi internal yaitu komitmen organisasi dan atribusi eksternal seperti kesulitan-kesulitan yang dijumpai saat mencapai target anggaran."

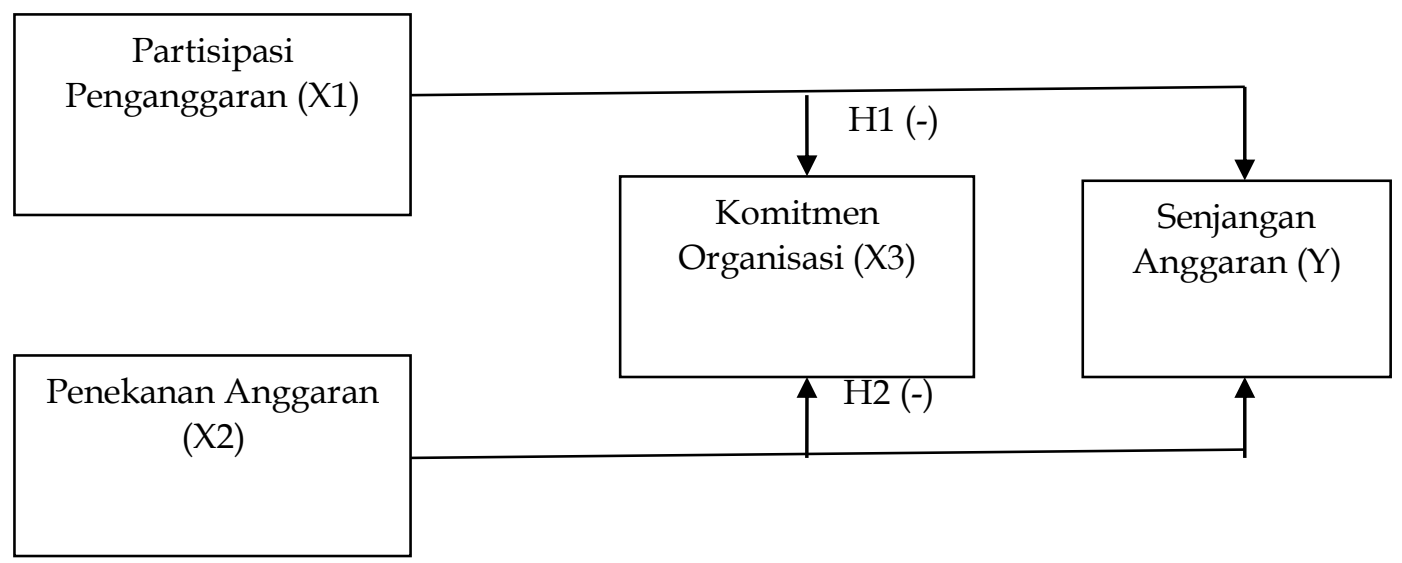

Sumber: Data Penelitian, 2020

\section{Gambar 1. Model Penelitian}

Implikasi partisipasi penyusunan anggaran pada senjangan anggaran adalah semakin tinggi partisipasi yang diberikan kepada bawahan, maka bawahan berusaha agar anggaran yang mereka susun mudah dicapai serta mengurangi risiko yang mungkin dihadapi apabila tidak mampu mencapai target yang diinginkan (Mahasabha \& Ratnadi, 2019).

Penelitian terdahulu yang dilakukan oleh Mahadewi (2014) dan Irfan et al., (2016) menyatakan bahwa komitmen organisasi memperlemah pengaruh positif partisipasi penganggaran pada senjangan anggaran. Dalam konsep senjangan anggaran, apabila seseorang memiliki komitmen organisasi yang tinggi akan taat pada pedoman penyusunan anggaran demi menjaga nama baik organisasi sehingga membuat hubungan antara partisipasi penganggaran dengan senjangan anggaran bersifat negatif. Berdasarkan alasan tersebut, hipotesis yang dapat dikembangkan dalam penelitian ini sebagai berikut.

$\mathrm{H}_{1}$ : Komitmen organisasi memperlemah pengaruh positif partisipasi penganggaran pada senjangan anggaran.

Implikasi penekanan anggaran pada senjangan anggaran terjadi ketika adanya penekanan anggaran mengakibatkan karyawan menjadi tegang, dan pada akhirnya akan memicu karyawan melakukan berbagai tindakan disfungsional seperti senjangan anggaran guna menghindari risiko apabila tidak tercapainya target anggaran (Ramgulam et al., 2012).

Penelitian mengenai kemampuan komitmen organisasi dalam memoderasi pengaruh penekanan anggaran pada senjangan anggaran telah dilakukan yaitu penelitian Wulandari (2017) dan Perdani (2019) yang menyatakan bahwa komitmen organisasi mampu memperlemah pengaruh positif penekanan anggaran pada senjangan anggaran. 
Apabila bawahan yang memiliki komitmen organisasi yang tinggi akan taat pada pedoman penyusunan anggaran sehingga membuat hubungan antara penekanan anggaran dengan senjangan anggaran bersifat negatif. Hal ini berarti pada saat komitmen organisasi tinggi, penekanan anggaran akan menyebabkan menurunnya senjangan anggaran. Berdasarkan alasan tersebut, hipotesis yang dapat dikembangkan dalam penelitian sebagai berikut.

$\mathrm{H}_{2}$ : Komitmen organisasi memperlemah pengaruh positif penekanan anggaran pada senjangan anggaran.

\section{METODE PENELITIAN}

Penelitian ini menggunakan pendekatan kuantitatif yang berbentuk penelitian asosiatif. Lokasi penelitian ini dilakukan pada 30 OPD di Kabupaten Klungkung (Jl. Untung Surapati No.2, Semarapura Tengah, Kec. Klungkung, Kabupaten Klungkung, Bali). Dipilihnya Organisasi Perangkat Daerah Klungkung dikarenakan di Laporan Realisasi APBD Kabupaten Klungkung tahun Anggaran 2014-2018 mengindikasikan adanya praktik senjangan anggaran. Objek dalam penelitian ini adalah Senjangan Anggaran yang diprediksi dengan partisipasi penganggaran, penekanan anggaran serta komitmen organisasi.

Populasi dalam penelitian ini adalah 90 penyusun anggaran yang tersebar di 30 Organisasi Perangkat Daerah (OPD) Kabupaten Klungkung. Sampel yang dipilih hanya yang berkaitan dengan proses penyusunan anggaran yaitu berjumlah 90 partisipan. Responden yang dianalisis yaitu berjumlah 68 partisipan yang sudah memenuhi kriteria pemilihan anggota sampel. Karakteristik responden dalam penelitian ini meliputi jenis kelamin, umur, pendidikan terakhir, jabatan, dan lama menduduki jabatan di OPD Kabupaten Klungkung. Metode penentuan sampel yang digunakan dalam penelitian ini menggunakan metode non probability sampling dengan teknik purposive sampling.

Adapun kriteria yang dijadikan dasar pemilihan anggota sampel dalam penelitian ini adalah kepala OPD, kepala sub bagian keuangan, dan kepala sub bagian perencanaan yang telah menduduki jabatan yang sama minimal 1 tahun dan ikut berpartisipasi dalam proses penyusunan anggaran pada OPD Kabupaten Klungkung. Kriteria digunakan karena berdasarkan Peraturan Bupati Klungkung Nomor 35 Tahun 2016 tentang kedudukan, susunan organisasi, tugas dan fungsi serta tata kerja perangkat daerah, jabatan tersebutlah yang bertugas mengumpulkan dan menelaah kembali anggaran yang dibuat oleh masing-masing bidang di dalam OPD.

Metode pengumpulan data yang dilakukan dalam penelitian ini adalah menggunakan kuesioner. Kuesioner yang disebar berupa daftar pertanyaan dan pernyataan tertulis kepada seluruh OPD Kabupaten Klungkung. Kuesioner yang digunakan dalam penelitian ini yaitu untuk mengukur variabel senjangan anggaran, partisipasi penganggaran, penekanan anggaran, dan komitmen organisasi. Teknik analisis data yang digunakan dalam penelitian ini adalah uji nilai selisih mutlak dengan menggunakan SPSS. Adapun tahapan analisis data yang dilakukan adalah uji asumsi klasik, uji nilai selisih mutlak, koefisien determinasi $\left(R^{2}\right)$, uji kelayakan model (Uji F), dan uji hipotesis (Uji t). Uji nilai selisih mutlak dalam penelitian ini dapat dirumuskan sebagai berikut. 


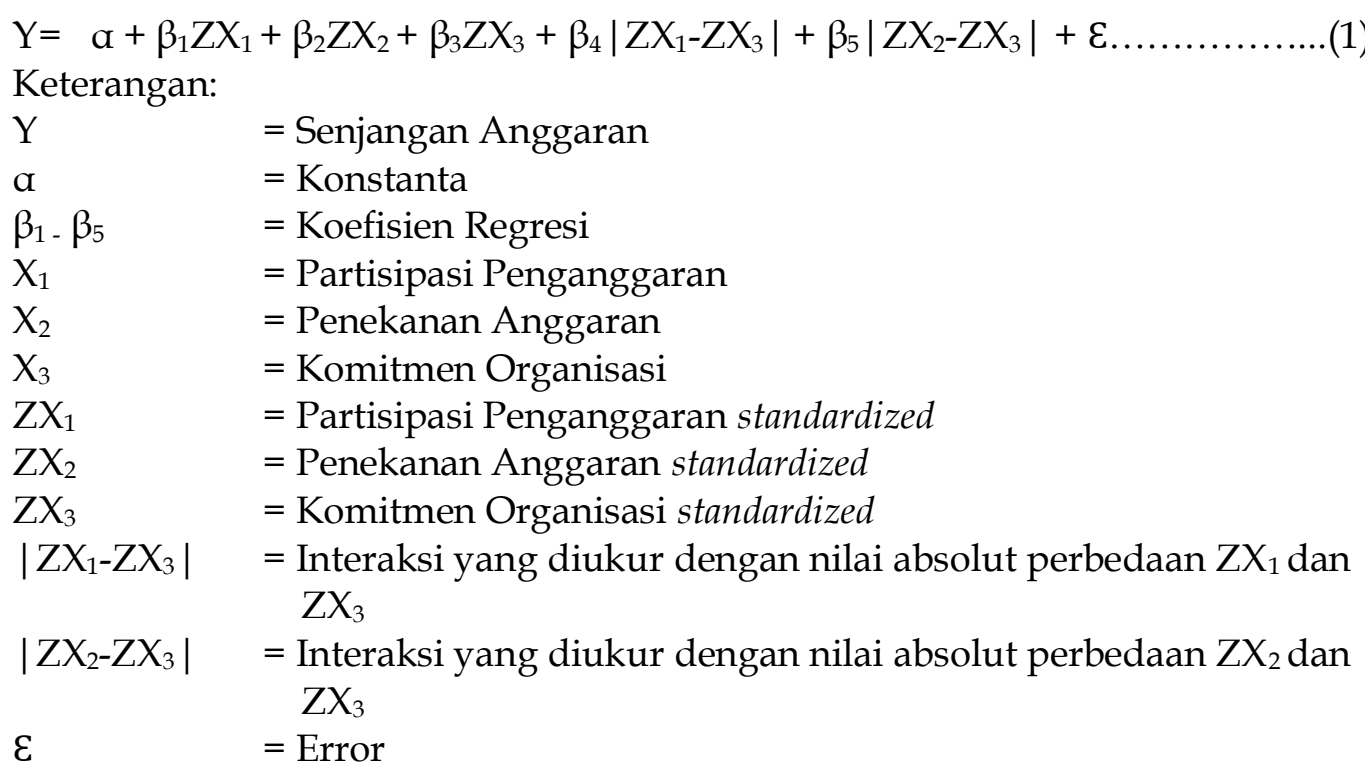

\section{HASIL DAN PEMBAHASAN}

Responden dalam penelitian ini adalah Kepala OPD, Kepala Sub Bagian Keuangan dan Kepala Sub Bagian Perencanaan yang telah menjabat minimal 1 tahun pada OPD Kabupaten Klungkung. Penyebaran kuesioner dilakukan secara langsung kepada masing-masing responden. Kuesioner yang disebar ke masingmasing OPD berisikan catatan mengenai siapa responden yang menjadi sasaran penelitian sehingga seluruh kuesioner diisi oleh responden yang tepat.

Sebanyak 90 kuesioner disebar kepada responden, namun setelah dilakukan konfirmasi, jumlah kuesioner yang dikembalikan sebanyak 87 kuesioner, sedangkan kuesioner yang tidak kembali sebanyak 3 kuesioner dan kuisioner yang tidak memenuhi kriteria sebanyak 19 kuisioner. Kuesioner yang tidak kembali dikarenakan adanya kesibukan dari OPD. Kuisioner yang tidak memenuhi kriteria disebabkan karena adanya Kepala OPD/Kepala Sub Keuangan/Kepala Sub Perencanaan yang menjabat kurang dari 1 tahun. Selain itu adanya pejabat yang merangkap menjadi Kepala sub Perencanaan dan Keuangan, hal ini terjadi dikarenakan perbedaan struktur organisasi di masingmasing OPD Kabupaten Klungkung. Berdasarkan uraian, kuesioner yang dapat digunakan dan telah memenuhi kriteria sebanyak 68 kuesioner atau sebesar 75 persen.

Sebelum kuesioner disebar ke 30 OPD di Kabupaten Klungkung, terlebih dahulu peneliti melakukan uji instrumen internal kepada 38 mahasiswa Program Studi Akuntansi FEB Unud angkatan 2016. Alasan menggunakan uji instrumen internal dikarenakan menggunakan pernyataan kuisioner yang telah digunakan pada riset-riset terdahulu. Pengujian instrumen meliputi uji validitas dan reliabilitas. Adapun hasil uji validitas dan reliabilitas untuk melihat apakah hasil pengujian instrumen valid dan reliabel.

Suatu kuesioner dikatakan valid jika kuesioner mampu untuk mengungkapkan suatu yang akan diukur oleh kuesioner tersebut. Suatu kuesioner dikatakan memenuhi uji validitas bila nilai $r$ hitung yang dilihat dari 
pearson correlation lebih besar dari 0,30 . Hasil uji validitas penelitian ini dapat dilihat pada Tabel 2.

Tabel 2. Rekapitulasi Hasil Uji Validitas

\begin{tabular}{|c|c|c|}
\hline Variabel & Kode Instrumen & Nilai Pearson Correlation \\
\hline$(1)$ & (3) & $(3)$ \\
\hline \multirow[t]{7}{*}{ Partisipasi Penganggaran } & $\mathrm{X}_{1.1}$ & 0,687 \\
\hline & $\mathrm{X}_{1.2}$ & 0,666 \\
\hline & $\mathrm{X}_{1.3}$ & 0,654 \\
\hline & $\mathrm{X}_{1.4}$ & 0,729 \\
\hline & $\mathrm{X}_{1.5}$ & 0,324 \\
\hline & $X_{1.6}$ & 0,646 \\
\hline & $\mathrm{X}_{1.7}$ & 0,776 \\
\hline \multirow[t]{6}{*}{ Penekanan Anggaran } & $\mathrm{X}_{2.1}$ & 0,568 \\
\hline & $\mathrm{X}_{2.2}$ & 0,649 \\
\hline & $\mathrm{X}_{2.3}$ & 0,469 \\
\hline & $\mathrm{X}_{2.4}$ & 0,631 \\
\hline & $\mathrm{X}_{2.5}$ & 0,638 \\
\hline & $X_{2.6}$ & 0,704 \\
\hline \multirow[t]{9}{*}{ Komitmen Organisasi } & $X_{3.1}$ & 0,671 \\
\hline & $\mathrm{X}_{3.2}$ & 0,680 \\
\hline & $X_{3.3}$ & 0,825 \\
\hline & $X_{3.4}$ & 0,754 \\
\hline & $\mathrm{X}_{3.5}$ & 0,688 \\
\hline & $X_{3.6}$ & 0,802 \\
\hline & $X_{3.7}$ & 0,485 \\
\hline & $\mathrm{X}_{3.8}$ & 0,735 \\
\hline & $\mathrm{X}_{3.9}$ & 0,759 \\
\hline \multirow[t]{8}{*}{ Senjangan Anggaran } & $Y_{1.1}$ & 0,577 \\
\hline & $\mathrm{Y}_{1.2}$ & 0,531 \\
\hline & $\mathrm{Y}_{1.3}$ & 0,432 \\
\hline & $\mathrm{Y}_{1.4}$ & 0,301 \\
\hline & $\mathrm{Y}_{1.5}$ & 0,771 \\
\hline & $\mathrm{Y}_{1.6}$ & 0,642 \\
\hline & $\mathrm{Y}_{1.7}$ & 0,339 \\
\hline & $\mathrm{Y}_{1.8}$ & 0,495 \\
\hline
\end{tabular}

Sumber: Data Penelitian, 2020

Berdasarkan hasil uji validitas, seluruh variabel dikatakan valid karena nilai pearson correlation lebih dari 0,3 . Hasil analisis realiabilitas atau kehandalan instrument menunjukkan sejauh mana suatu pengukuran dapat memberikan 
hasil yang konsisten bila dilakukan pengukuran kembali. Suatu kuesioner dikatakan memenuhi uji reliabilitas jika nilai dari Cronbach's Alpha $\geq 0,60$

Tabel 3. Rekapitulasi Hasil Uji Reliabilitas

\begin{tabular}{llc}
\hline No & Variabel & Cronbach's Alpha \\
\hline 1 & Partisipasi Pengangaran $\left(\mathrm{X}_{1}\right)$ & 0,760 \\
2 & Penekanan Anggaran $\left(\mathrm{X}_{2}\right)$ & 0,664 \\
3 & Komitmen Organisasi $\left(\mathrm{X}_{3}\right)$ & 0,875 \\
4 & Senjangan Anggaran $(\mathrm{Y})$ & 0,619 \\
\hline
\end{tabular}

Sumber: Data Penelitian, 2020

Berdasarkan hasil uji reliabilitas dapat dilihat bahwa nilai Conbrach's Alpha masing-masing variabel lebih dari 0,60. Hal ini menunjukkan bahwa seluruh pertanyaan dalam kuesioner penelitian ini realiabel dan dapat digunakan. Statistik deskriptif dalam penelitian ini disajikan untuk memberikan informasi tentang karakteristik variabel penelitian antara lain jumlah sampel, nilai minimum, nilai maksimum, nilai rata-rata (mean), dan standar deviasi dari masing-masing variabel.

Tabel 4. Hasil Uji Deskriptif Variabel Penelitian

\begin{tabular}{lccccc}
\hline Variabel & $\mathrm{N}$ & Minimum & Maksimum & $\begin{array}{l}\text { Rata- } \\
\text { Rata }\end{array}$ & $\begin{array}{l}\text { Standar } \\
\text { Deviasi }\end{array}$ \\
\hline$(1)$ & $(2)$ & $(3)$ & $(4)$ & $(5)$ & $(6)$ \\
\hline Partisipasi Penganggaran $\left(\mathrm{X}_{1}\right)$ & 68 & 2,4 & 3,9 & 3,082 & 0,3090 \\
Penekanan Anggaran $\left(\mathrm{X}_{2}\right)$ & 68 & 2,0 & 4,0 & 3,184 & 0,5015 \\
Komitmen Organisasi $\left(\mathrm{X}_{3}\right)$ & 68 & 2,0 & 4,0 & 3,104 & 0,4689 \\
Senjangan Anggaran $(\mathrm{Y})$ & 68 & 2,1 & 3,8 & 3,159 & 0,3670 \\
Valid N (listwise) & 68 & & & & \\
\hline
\end{tabular}

Sumber: Data Penelitian, 2020

Variabel partisipasi penganggaran memiliki nilai minimum sebesar 2,4 dan nilai maksimum sebesar 3,9 dengan nilai rata-rata sebesar 3,082. Nilai ratarata tersebut memiliki kecenderungan mendekati nilai maksimum yang artinya responden cenderung menyetujui pernyataan terkait partisipasi penganggaran, sehingga dapat dikatakan partisipasi penganggaran di OPD Kabupaten Klungkung cenderung tinggi.

Nilai standar deviasi pada variabel partisipasi penganggaran adalah sebesar 0,309, nilai tersebut lebih rendah dibandingkan nilai rata-ratanya. Hal ini menunjukkan bahwa data penelitian bersifat homogen sehingga dapat dikatakan bahwa sebagian besar OPD di Kabupaten Klungkung memiliki tingkat partisipasi penganggaran yang sama.

Variabel penekanan anggaran memiliki nilai minimum sebesar 2,00 dan nilai maksimum sebesar 4,00, dengan nilai rata-rata sebesar 3,184 yang artinya responden cenderung menyetujui pernyataan terkait penekanan anggaran, sehingga dapat dikatakan penekanan anggaran di OPD Kabupaten Klungkung cenderung tinggi. Nilai standar deviasi pada variabel partisipasi penganggaran adalah sebesar 0,5015, nilai tersebut lebih rendah dibandingkan nilai rataratanya. Hal ini menunjukkan bahwa data penelitian bersifat homogen sehingga dapat dikatakan bahwa sebagian besar OPD di Kabupaten Klungkung memiliki tingkat penekanan anggaran yang sama. 
Variabel komitmen organisasi memiliki nilai minimum sebesar 2,00 dan nilai maksimum sebesar 4,00, dengan nilai rata-rata sebesar 3,104 yang artinya responden cenderung menyetujui pernyataan terkait komitmen organisasi, sehingga dapat dikatakan komitmen organisasi di OPD Kabupaten Klungkung cenderung tinggi. Nilai standar deviasi pada variabel komitmen organisasi adalah sebesar 0,4689 , nilai tersebut lebih rendah dibandingkan nilai rataratanya. Hal ini menunjukkan bahwa data penelitian bersifat homogen sehingga dapat dikatakan bahwa sebagian besar OPD di Kabupaten Klungkung memiliki tingkat komitmen organisasi yang sama.

Variabel senjangan anggaran memiliki nilai minimum sebesar 2,1 dan nilai maksimum sebesar 3,8, dengan nilai rata-rata sebesar 3,159. Nilai rata-rata tersebut memiliki kecenderungan mendekati nilai maksimum yang artinya responden cenderung menyetujui pernyataan terkait senjangan anggaran, sehingga dapat dikatakan senjangan anggaran di OPD Kabupaten Klungkung cenderung tinggi. Nilai standar deviasi pada variabel senjangan anggaran adalah sebesar 0,367, nilai tersebut lebih rendah dibandingkan nilai rata-ratanya. Hal ini menunjukkan bahwa data penelitian bersifat homogen sehingga dapat dikatakan bahwa sebagian besar OPD di Kabupaten Klungkung memiliki tingkat senjangan anggaran yang sama.

\section{Tabel 5. Hasil Uji Normalitas}

\begin{tabular}{lc}
\hline $\mathrm{N}$ & Unstandardized Residual \\
Kolmogorov-Smirnov Z & 68 \\
Asymp. Sig. (2-tailed) & 0,727 \\
\hline
\end{tabular}

Sumber: Data Penelitian, 2020

Berdasarkan Tabel 5, menunjukkan bahwa hasil uji normalitas koefisien Asymp. Sig (2-tailed) memiliki nilai 0,081 yang artinya data dalam penelitian ini berdistribusi normal.

Tabel 6. Hasil Uji Heteroskedastisitas

\begin{tabular}{lrrrrr}
\hline & \multicolumn{2}{c}{$\begin{array}{c}\text { Unstandardized } \\
\text { Coefficients }\end{array}$} & $\begin{array}{c}\text { Standardized } \\
\text { Coefficients }\end{array}$ & & \\
\cline { 2 - 4 } & \multicolumn{1}{c}{$\mathrm{B}$} & Std. Error & Beta & $\mathrm{t}$ & \multicolumn{1}{c}{ Sig. } \\
\hline (Constant) & $-0,032$ & 1,358 & & $-0,024$ & 0,981 \\
Partisipasi Penganggaran & $-0,009$ & 0,085 & $-0,020$ & $-0,106$ & 0,916 \\
Penekanan Anggaran & 0,015 & 0,045 & 0,045 & 0,335 & 0,739 \\
Komitmen Organisasi & 0,031 & 0,042 & 0,128 & 0,746 & 0,459 \\
$\mid$ ZX1-ZX3 & 0,161 & 0,069 & 0,600 & 2,329 & 0,073 \\
$\mid$ ZX2-ZX3 & 0,105 & 0,088 & $-0,317$ & $-1,200$ & 0,235 \\
\hline
\end{tabular}

Sumber: Data Penelitian, 2020

Berdasarkan Tabel 6, dapat dilihat bahwa masing-masing variabel memiliki nilai signifikansi lebih besar dari taraf signifikansi 0,05. Variabel partisipasi penganggaran memiliki nilai signifikansi sebesar 0,916, variabel penekanan anggaran memiliki nilai signifikansi sebesar 0,739, variabel komitmen organisasi memiliki nilai signifikansi sebesar 0,459, variabel interaksi partisipasi penganggaran dan komitmen organisasi memiliki nilai signifikansi sebesar 0,073 dan variabel interaksi penekanan anggaran dan komitmen organisasi memiliki nilai signifikansi sebesar 0,235. Nilai-nilai tersebut lebih besar dari 0,05 yang 
berarti tidak terdapat pengaruh antara variabel bebas terhadap absolute residual. Dengan demikian, model tersebut bebas dari gejala heteroskedastisitas.

Berdasarkan Tabel 7, disusun persamaan regresi sebagai berikut. $Y=18,014+0,743 X_{1}-0,182 X_{2}-0,400 X_{3}-0,344\left|Z X_{1}-Z X_{3}\right|+0,884\left|Z_{2}-Z_{3}\right|$ Tabel 7. Hasil Uji Nilai Selisih Mutlak

\begin{tabular}{|c|c|c|c|c|c|}
\hline \multirow[t]{2}{*}{ Variabel } & \multicolumn{2}{|c|}{ Unstandardize Coefficient } & \multirow{2}{*}{$\begin{array}{l}\text { Standardize } \\
\text { Coefficient }\end{array}$} & \multirow[t]{2}{*}{$\mathrm{t}$} & \multirow[t]{2}{*}{ Sig } \\
\hline & B & Std. Error & & & \\
\hline (1) & $(2)$ & $(3)$ & $(4)$ & (5) & (6) \\
\hline Constant & 18,014 & 2,265 & & 7,955 & 0,000 \\
\hline $\begin{array}{l}\text { Partisipasi } \\
\text { Penganggaran }\end{array}$ & 0,743 & 0,141 & 0,551 & 5,262 & 0,000 \\
\hline $\begin{array}{l}\text { Penekanan } \\
\text { Anggaran }\end{array}$ & $-0,182$ & 0,075 & $-0,185$ & $-2,428$ & 0,018 \\
\hline $\begin{array}{l}\text { Komitmen } \\
\text { Organisasi }\end{array}$ & $-0,400$ & 0,069 & $-0,561$ & $-5,767$ & 0,000 \\
\hline$\left|Z X_{1}-Z X_{3}\right|$ & $-0,344$ & 0,115 & $-0,434$ & $-2,983$ & 0,004 \\
\hline$\left|Z X_{2}-Z X_{3}\right|$ & 0,884 & 0,146 & 0,902 & 6,047 & 0,000 \\
\hline Adjusted $R_{\text {square }}$ & 0,741 & & & & \\
\hline $\mathrm{F}_{\text {hitung }}$ & 35,397 & & & & \\
\hline Sig. F Fitung & 0,000 & & & & \\
\hline
\end{tabular}

Sumber: Data Penelitian, 2020

Dari Persamaan (2) diketahui bahwa nilai konstanta (a) menunjukkan nilai positif sebesar 18,014 . Nilai tersebut memiliki arti jika variabel partisipasi penganggaran, penekanan anggaran, komitmen organisasi, interaksi partsipasi penganggaran dengan, komitmen organisasi dan interaksi penekanan anggaran dengan komitmen organisasi dinyatakan konstan pada angka 0, maka nilai senjangan anggaran akan tetap terjadi.

Berdasarkan persamaan (2), terlihat bahwa variabel partisipasi penganggaran memiliki koefisien bernilai positif. Hal ini menunjukkan terdapat pengaruh positif variabel partisipasi penganggaran pada senjangan anggaran, sedangkan variabel penekanan anggaran dan komitmen organisasi memiliki koefisien bernilai negatif, yang menunjukkan terdapat pengaruh negatif variabel penekanan anggaran dan komitmen organisasi pada senjangan anggaran.

Interaksi variabel partisipasi penganggaran dengan komitmen organisasi $\left|Z_{1}-Z_{3}\right|$ memiliki pengaruh negatif pada senjangan anggaran. Hal ini berarti bahwa interaksi partisipasi penganggaran dan komitmen organisasi berbanding terbalik dengan senjangan anggaran. Nilai koefisien regresi menjelaskan bahwa setiap kenaikan variabel interaksi partisipasi penganggaran dan komitmen organisasi maka nilai dari senjangan anggaran akan mengalami penurunan dengan asumsi variabel bebas lainnya konstan

Interaksi variabel penekanan anggaran dengan komitmen organisasi $\left|Z_{2}-Z_{3}\right|$ memiliki pengaruh positif pada senjangan anggaran. Hal ini berarti bahwa interaksi penekanan anggaran dan komitmen organisasi sebanding dengan senjangan anggaran. Nilai koefisien regresi menjelaskan bahwa setiap kenaikan variabel interaksi penekanan anggaran dan komitmen organisasi maka nilai dari senjangan anggaran akan mengalami peningkatan dengan asumsi variabel bebas lainnya konstan. 
Berdasarkan Tabel 7, dapat dilihat nilai Adjusted $\mathrm{R}^{2}$ sebesar 0,741. Ini berarti bahwa 74,1 persen variasi variabel senjangan anggaran mampu dijelaskan oleh variabel partisipasi penganggaran, penekanan anggaran, dan komitmen organisasi, sedangkan sisanya sebesar 25,9 persen dijelaskan oleh faktor-faktor lain yang tidak dijelaskan dalam penelitian ini. Berdasarkan Tabel 7, dapat dilihat bahwa nilai Sig.F sebesar 0,000 lebih kecil daripada 0,05 hal ini berarti bahwa partisipasi penganggaran, penekanan anggaran, interaksi antara partisipasi penganggaran dengan komitmen organisasi dan interaksi antara penekanan anggaran dengan komitmen organisasi dapat memprediksi atau menjelaskan fenomena senjangan anggaran pada OPD Kabupaten Klungkung, sehingga dapat disimpulkan bahwa model dalam penelitian ini dikatakan layak untuk diteliti.

Hipotesis satu $\left(\mathrm{H}_{1}\right)$ menyatakan bahwa komitmen organisasi memperlemah pengaruh positif partisipasi penganggaran pada senjangan anggaran. Berdasarkan uji hipotesis menunjukkan bahwa komitmen organisasi memperlemah pengaruh positif partisipasi penganggaran pada senjangan anggaran, sehingga Hipotesis satu $\left(\mathrm{H}_{1}\right)$ diterima. Tingginya tingkat partisipasi penganggaran menyebabkan penyusun anggaran cenderung memberikan estimasi yang bukan estimasi anggaran yang terbaik bagi suatu organisasi. Hal ini sejalan dengan teori keagenan yang menyatakan adanya benturan kepentingan yang terjadi melalui partisipasi penganggaran. Hasil penelitian ini sejalan dengan beberapa penelitian terdahulu yaitu penelitian yang dilakukan oleh Mahadewi (2014) dan Irfan et al., (2016) yang menyatakan bahwa komitmen organisasi memperlemah pengaruh partisipasi penganggaran pada senjangan anggaran.

Hipotesis dua $\left(\mathrm{H}_{2}\right)$ menyatakan bahwa komitmen organisasi memperlemah pengaruh positif penekanan anggaran pada senjangan anggaran. Berdasarkan uji hipotesis menunjukkan bahwa komitmen organisasi memperlemah pengaruh negatif penekanan anggaran pada senjangan anggaran, sehingga Hipotesis dua $\left(\mathrm{H}_{2}\right)$ ditolak. Hal ini juga sejalan dengan teori keagenan yang menyatakan bahwa terdapat benturan kepentingan dalam konsep senjangan anggaran. Dalam perspektif teori keagenan, bagi bawahan yang memiliki komitmen organisasi tinggi akan menunjukkan loyalitasnya pada organisasi tempatnya bekerja dengan cara mengupayakan segala hal agar kinerja organisasi tempatnya bekerja seolah-olah terlihat baik. Salah satunya yaitu dengan melonggarkan anggaran agar mudah tercapai, hal inilah yang mampu memicu terjadinya senjangan anggaran. Hasil ini sejalan dengan penelitian Lestari dan Putri (2015) serta Chong dan Strauss (2017) yang menyatakan bahwa penekanan anggaran berpengaruh negatif pada senjangan anggaran.

\section{SIMPULAN}

Berdasarkan hasil analisis dan pembahasan yang telah dipaparkan pada bab sebelumnya, didapatkan simpulan sebagai berikut. 1) Komitmen organisasi memperlemah pengaruh positif partisipasi penganggaran pada senjangan anggaran. 2) Komitmen organisasi memperlemah pengaruh negatif penekanan anggaran pada senjangan anggaran. 
Saran yang dapat diberikan berdasarkan hasil penelitian adalah sebagai berikut: Bagi Responden, diharapkan memperhatikan dan meningkatkan tuntutan tanggung jawab anggaran agar senjangan anggaran dapat diminimalisir. Bagi atasan di masing-masing OPD Kabupaten Klungkung, sebaiknya melakukan pengawasan, pemeriksaan dan penelaahan kembali anggaran yang telah diusulkan oleh bawahan secara lebih ketat serta tidak menggunakan anggaran sebagai satu-satunya alat untuk mengukur kinerja sehingga senjangan anggaran dapat diminimalisir. Selain itu, pihak-pihak yang terlibat dalam proses penganggaran harus memiliki komitmen organisasi yang tinggi sehingga penyusun anggaran dapat menentukan kebijakan-kebijakan yang terbaik bagi kelangsungan organisasi yang dapat meminimalisir terjadinya senjangan anggaran.

\section{REFERENSI}

Ajibolade, S. O., \& Akinniyi, O. K. (2013). The influence of organisational culture and budgetary participation on propensity to create budgetary slack in public sector organisations. British Journal of Art and Social Science, 13(I), 6983.

Bupati Klungkung. Peraturan Bupati Nomor 35 Tahun 2016 Tentang Kedudukan, Susunan Organisasi, Tugas dan Fungsi serta Tata Kerja Perangkat Daerah. (2016). Indonesia.

Carreras, M. G., \& Gil, D. N. (2014). Trust in Superiors and Dysfunctional Behaviors : an Experimental Study on Budgetary Slack. Journal of Positive Management, 5(1), 54. https:/ / doi.org/10.12775/jpm.2014.006

Chong, V. K., \& Strauss, R. (2017). Participative budgeting: The effects of budget emphasis, information asymmetry and procedural justice on slack additional evidence. Asia-Pacific Management Accounting Journal, 12(1), 181220.

Dewi, N. L. P. S. (2013). Analisis Pengaruh Anggaran Partisipatif pada Budgetary Slack dengan Empat Variabel Moderasi (Studi Kasus pada SKPD Kabupaten Badung, Bali). Universitas Udayana.

Djasuli, M., \& Fadilah, N. I. (2011). Efek Interaksi Informasi Asimetri, Budaya Organisasi, Group Cohesiveness dan Motivasi dalam Hubungan Kausal antara Budgeting Participation dan Budgetary Slack. Jurnal Fakultas Ekonomi Universitas Trunodjoyo Madura, 4.

Dunk, A. S. (1993). The Effect Relation of Budget Between Emphasis the Budgetary Slack and Information Asymmetry on Participation and Slack. The Accounting Review, 68(2), 400-410.

Erina, N. P. D., \& Suartana, W. (2016). Pengaruh Partisipasi Penganggaran, Penekanan Anggaran, Kapasitas Individu, dan Kejelasan Sasaran Anggaran pada Senjangan Anggaran. E-Jurnal Ekonomi Dan Bisnis Universitas Udayana, 15(2), 973-1000.

Falikhatun. (2007). Pengaruh Partisipasi Penganggaran Terhadap Budgatary Slack dengan Variabel Pemoderasi Ketidakpastian Lingkungan dan Kohesifitas Kelompok. Jurnal Akuntansi Dan Keuangan, 16(2), 207-221. https:// doi.org/10.1017/CBO9781107415324.004

Faria, J. A. de, \& Silva, S. M. G. da. (2013). The effects of information asymmetry 
on budget slack: An experimental research. African Journal of Business Management, 7(13), 1086-1099. https:// doi.org/10.5897/AJBM2013.1641

Govindarajan, V. (1986). Impact of Participation in The Budgetary Process on Managerial Attitudes and Performance: Universalistic and Contingency Perspectives.

Harvey, M. E. (2015). The Effect Of Employee Ethical Ideology on Organizational Budget Slack: An Empirical Examination and Practical Discussion. Journal of Business E Economics Research, 13(1), 83-90.

Heider, F. (1958). The Psychology of Interpersonal Relations. New York: John Wiley and Sons.

Irfan, M., Santoso, B., \& Effendi, L. (2016). Pengaruh Partisipasi Anggaran terhadap Senjangan Anggaran dengan Asimetri Informasi, Penekanan Anggaran dan Komitmen Organisasional sebagai Variabel Pemoderasi. 17(2), 158-175. https:/ / doi.org/10.18196/jai.2016.0052.158-175

Jensen, M. C., \& Meckling, W. H. (1976). Theory of the Firm: Managerial Behavior, Agency Costs and Ownership Structure. Journal of Financial Economics, 3(4), 305-360. https://doi.org/http://dx.doi.org/10.1016/0304405X(76)90026-X

Karsam. (2013). The Influence of Participation in Budgeting on Budgetary Slack with Information Asymmetry as a Moderating Variable and Its Impact on the Managerial Performance (A Study on Yayasan Pendidikan dan Koperasi in the Province of Banten, Indonesia). International Journal of Applied Finance and Business Studies, 1(1), 28-38.

Klungkung. Web Site Resmi Pemerintahan Kabupaten Klungkung. Retrieved from https://www.klungkungkab.go.id/

Lavarda, C. E. F., \& Almeida, D. M. (2013). Budget Participation and informational Asymmetry: A Study in A Multinational Company. Brazilian Business Review, 10(2), 72-94. https:/ / doi.org/http://dx.doi.org/10.15728/bbr.2013.10.2.4 Budget

Lestari, N. K. T., \& Putri, I. A. D. (2015). Pengaruh Penganggaran Partisipatif pada Senjangan Anggaran Dimoderasi Ketidakpastian Lingkungan dan Komitmen Organisasi. E-Jurnal Akuntansi Universitas Udayana, 10(2), 474488.

Mahadewi, A. A. S. S. (2014). Pengaruh Partisipasi Penganggaran pada Senjangan Anggaran dengan Asimetri Informasi dan Komitmen Organisasi sebagai Pemoderasi. E-Jurnal Akuntansi Universitas Udayana, 8(3), 458-473.

Mahasabha, N. L. A., \& Ratnadi, N. M. D. (2019). Pengaruh Partisipasi Penganggaran dan Penekanan Anggaran Pada Senjangan Anggaran Dengan Locus of Control Sebagai Pemoderasi. E-Jurnal Akuntansi Universitas Udayana, 26(3), 2123-2154. https:/ / doi.org/https:/ / doi.org/10.24843/EJA.2019.v26.i03.p17

Mardiasmo. (2018). Akuntansi Sektor Publik. Yogyakarta: ANDI.

Perdani, A. N. (2019). The Effect of Budget Participation and Budget Emphasis on Budget Slack with Organizational Commitment as A Moderating Variable in Local Government Agencies (Study case in SKPD Bengkulu City and Seluma District). Universitas Islam Indonesia.

Pratami, A. A. S. D., \& Erawati, N. M. A. (2016). Pengaruh Partisipasi 
Penganggaran Terhadap Senjangan Anggaran dengan Penekanan Anggaran dan Ketidakpastian Lingkungan Sebagai Pemoderasi. E-Jurnal Akuntansi Universitas Udayana, 15(2), 1565-1594.

Ramgulam, N., Student, M. S., Fyfe, D., Kistow, B., Allaham, I., Raghunandan, R. K., \& Students, M. S. (2012). Examining the Behavioural Aspects of Budgeting with particular emphasis on Public Sector / Service Budgets Moolchand Raghunandan ( Lecturer in Accounting ) Koshina Raghunandan-Mohammed (Assistant Lecturer in Accounting ) With significant contributions fr. International Journal of Business and Social Science, $3(14), 110-117$.

Savitri, E., \& Sawitri, E. (2014). Pengaruh Partisipasi Anggaran, Penekanan Anggaran, dan Informasi Asimetri terhadap Timbulnya Kesenjangan Anggaran. Jurnal Akuntansi, 2(2), 210-226.

Suartana, I. W. (2010). Akuntansi Keperilakuan. Yogyakarta: ANDI.

Sudaryo, Y., Sjarif, D., Bandung, S. I., \& Sofiati, N. A. (2017). Keuangan di Era Otonomi Daerah. Yogyakarta: ANDI.

Sujana, I. K. (2010). Pengaruh Partisipasi Penganggaran, Penekanan Anggaran, Komitmen Organisasi, Asimetri Informasi dan Ketidakpastian Lingkungan terhadap Budgetary Slack pada Hotel-Hotel Berbintang di Kota Denpasar. Jurnal Ilmiah Akuntansi Dan Bisnis, 5(2).

Surya, M. (2019). Tiga koruptor anggaran instalasi biogas Klungkung dituntut 1,5 tahun penjara. Antara News Bali. Retrieved from https:/ / bali.antaranews.com/berita/146784/tiga-koruptor-anggaraninstalasi-biogas-klungkung-dituntut-15-tahun-penjara

Syahputra, Z. (2014). Influence of Locus of Control and Organizational Commitment on Job Satisfaction Moderated by Organizational Culture and Its Impact on Job Performance (Study of Employee's Aceh Local Government). Journal of Economics and Sustainable Development Www.Iiste.Org ISSN, 5(17), 104-111. Retrieved from www.iiste.org

Tagwireyi, F. (2012). an Evaluation of Budgetary Slack in Public Institutions in Zimbabwe. International Journal of Economics and Research, 03(04), 38-41.

Undang-Undang Republik Indonesia Nomor 23 Tahun 2014 Tentang Pemerintah Daerah. , (2014). Indonesia.

Widanaputra, A. A., \& Mimba, N. P. S. H. (2014). The Influence of Participative Budgeting on Budgetary Slack in Composing Local Governments ' Budget in Bali Province. Procedia - Social and Behavioral Sciences, 164, 391-396. https:// doi.org/10.1016/j.sbspro.2014.11.093

Windarti, A. (2015). Pengaruh Anggaran Belanja Daerah Dan Senjangan Anggaran Terhadap Tingkat Korupsi Di Indonesia. SALAM: Jurnal Sosial Dan Budaya Syar-I, 2(2), 1-25. https:/ / doi.org/10.15408/sjsbs.v2i2.2384

Wulandari, W. R. (2017). Pengaruh Kejelasan Sasaran Anggaran dan Penekanan Anggaran terhadap Senjangan Anggaran dengan Komitmen Organisasi sebagai Variabel Moderasi (Studi Empiris pada SKPD Kabupaten Indragiri Hulu). JOM Fekon, 4(1), 16-29. https:/ / doi.org/10.1017/CBO9781107415324.004 